\title{
Tóbiás László: Szakmai életutak az ifjúsági munkában: Katona Mária
}

Ifjúsági munkások szakmai életútját bemutató interjúsorozatunk harmadik darabja Katona Máriával készült, aki Békéscsabán és Debrecenben dolgozott ifjúsági munkásként. Közmüvelődési diplomával lépett a szakmába 1980-ban. Első két munkahelyén KISZ-klubot vezetett, bár ő maga már a főiskolán kilépett a Kommunista Ifjúsági Szövetségből. A Kossuth Egyetem Közmüvelődési Titkárságán végzett munkájából már nem a müvelődésszervezést, hanem a közösségek támogatását látja elsődlegesnek. Már első munkahelyén kapcsolatba lépett a közösségszervezők körével. Élete két szakaszában is formálója volt az ifjúságpolitikának. Előbb a rendszerváltást megelőző években, amikor a megyei tanács ifjúsági osztálya két munkatársa egyikeként részese volt az ifjúsággal kapcsolatos állami szerepek keresésének, megyei nemzetközi kapcsolatok megteremtésének. Másodszor pedig 2000-2013 között, amikor az Észak-alföldi Regionális Ifjúsági Szolgáltató Iroda vezetőjeként a Regionális Ifjúsági Tanács titkáraként is dolgozott, javaslattevői és megvalósítói feladatkörökkel. Mindkét esetben központi költségvetési forrás adott játékteret. Katona Máriának szerepe volt abban, hogy a régióban egyedi kezdeményezések is megvalósultak. Amikor 2013-ban felszámolták a regionális ifjúsági szolgáltató irodákat, a Nemzeti Művelődési Intézet megyei módszertani munkatársa lett. A segítő szakmák indulása idején tagja volt a humán szolgáltatások megteremtésén dolgozó körnek, de soha nem gondolta, hogy a szociális munkára cserélné az ifjúsági munkát.

Kulcsszavak: Mezon Ifjúsági Információs és Tanácsadó Iroda, Mobilitás Észak-alföldi Regionális Ifjúsági Szolgáltató Iroda, Mobilitás Könyvek, Látóutak, Vincze Béla

Katona Mária 1956-ban született Szeghalmon, két fiúgyermek után. Édesapjuk vasúti állomásfönök volt, édesanyjuk a gyerekekkel töltött évek után adminisztrátorként dolgozott. Kevéssel Katona Mária születése után édesapjukat Komádiba helyezték, 9 évet éltek az ottani állomásépületben, amit 3 kilométer és a Sebes-Körös választ el a falutól. Korlátok és féltések nélküli gyerekkort élhettek meg. A kendergyári lakótelep lakói előtt színházi előadással produkálták magukat, az állatvásárba messziről érkezőknek ivóvizet árultak. Úgy látja, gyermekkora meghatározó élményei kreativitását, szervezőképességét, munkában való igényességét alapozták meg. Szeghalomban érettségizett a Péter András által alapított, az utódok által róla elnevezett gimnáziumban. A gyermektelen földbirtokos a vagyonát Sárrét gyerekeinek iskoláztatására rendelte, és ezzel programot adott nem csak a tanároknak, de a diákoknak is. A gimnázium jó hírneve és szellemisége a már végzett diákokban erős kötődést alakított ki volt alma materük iránt. A Debrecenbe származott egykori gimnazisták is megalapították a Szeghalmi Öregdiákok Egyesületét, melyben, Katona Mária is aktívan részt vett. Egykori osztályfönöke egy érettségi találkozón idézte fel a róla szóló jellemzésből, hogy kritikus gondolkodású, jó kezdeményező- és szervezőképességgel rendelkezik. Kétszer futott neki a régész szaknak, választását motiválta, hogy naponta elbiciklizett Vésztő-Mágorra az ásatásokhoz, meg hogy inkább akart tárgyakkal foglalkozni, mint emberekkel. A második sikertelen felvételi - és egyfajta üvegplafon felismerése - után a korban gyakori taktikát választotta: valami felsőoktatást elkezdeni, majd átjelentkezni a vágyott szakra. Az Egri Ho Si 
Minh Tanárképző Főiskola tizenöt fős történelem-népmüvelés szakpárja és két oktató rabul ejtette. Köpf László tanszékvezető és Pápay Zsuzsa szociológus számára fontos volt, hogy milyen emberekké és szakemberekké válnak majd hallgatóik. Egy korábban végzett diák, Müller Károly vezetésével már müködött a föiskola pinceklubja, és a hallgatók ott szereztek gyakorlatot a diáktársaknak és a városnak szervezve programokat. Ezt ugyan nem tartja magának a szakmának Katona Mária, de elengedhetetlen tudást szereztek önkéntes munkájukkal választott szakmájukhoz. Az 1980-ban megszerzett első diplomától egyenesnek tartja az útját az ifjúsági munka területén. Úgy látja, az élet elakadások és jelentősebb küzdelmek nélkül adott újabb lehetőségeket, amikor ő úgy érezte, hogy már nem tud továbblépni, fejlődni, ahol éppen van. Mindig kínálkozott az ifjúsági munkában új lehetőség számára. Az ifjúsági munkában töltött 35 évet nem élte meg munkának, hanem küldetésnek érezte, amiben jól érezte magát. Békéscsabán az ipari szövetkezetek jó nevü Gyopár klubja vezetését vette át. Igyekezett szövetséget kötni a régi tagokkal, és teret nyitni a még fiatalabbaknak, és saját elképzeléseit is megvalósítani. A fenntartó szemet hunyt felette, hogy már nem csak a dolgozóinak szólt a klub. Bevonzotta látogatóként a helyi értelmiséget, müvészeket is, értékes programokat kínálva számukra is, mint közönségnek. Ekkor jelent meg munkájában az a célkitűzés, hogy el kell varázsolni a megcélzott közönséget azzal, amit kínál, és ahogyan, így szülessenek maradandó élmények. A középiskolások háromszoros teltházakkal igazolták vissza a munkáját. Cseh Tamás, Hobó és a Mozgó Világ estjei nyomán kezdhették megfigyelni, amit egészen a rendszerváltásig folytathattak.

'84. március 15. óta él Debrecenben. Az építőipari vállalat ifjúsági klubját vezetve sokat tanult arról, hogy a fiatalok szükségletei nem is olyan nagyon különböznek az iskolázottság szerint. 1985-től az egyetem közmüvelődési titkárságán szervezett rendezvényeket, amiknek az egyetem és a város közelítése is célja volt, de szakmai életútjában azért látja ezt az állomást meghatározónak, mert már nem az volt a fontos, hogy eseményeket hozzon létre, hanem a fiatalok szerveződéseinek, közösségeinek a támogatása. Az önszerveződések közül a Szép klub tevékenységei voltak a legkarakteresebbek. Az azt létrehozó, két meghatározó taggal, Halász Jánossal, Jantyik Zsolttal évtizedekkel később is volt erős bizalomra, egymás tiszteletére alapuló szakmai kapcsolata.

1987-ben az Állami Ifjúsági és Sporthivatal megalakításakor, annak megyei leképezéseként, bővítették a megyei tanács sportosztályát ifjúsági feladatkörrel, aminek mibenlétéről senkinek sem volt elképzelése, így Csontos János osztályvezetővel maguk találhatták ki a tevékenységeiket. A módszertani és a nemzetközi ifjúsági munka, a tapasztalatcserék akkor kerültek Katona Mária érdeklődése homlokterébe. Gyakran hivatkozza, hogy mennyit tanult az akkor született kapcsolatok révén Wootsch Pétertől és Kovács Erzsébettől. Az egyik legjobb, legőszintébb fejlesztő eszközüknek a letétiszámla-rendszert tartja, tisztább volt, mint a későbbi pályázati rendszerek. A pályázók között ismerte meg Vincze Bélát, akivel összekapcsolódott szakmai pályájuk, többször dolgoztak is együtt. Egy Katona Mária által szervezett ausztriai tapasztalatcserén talált rá a Rocksuli ötletére Vincze Béla, aki meg az általa vezetett Mezon Ifjúsági Információs és Tanácsadó Irodába hívta Katona Máriát 1990-ben, és tőle vette át a vezetést 1993-ban. Abban az időben szervezett a Humán Fejlesztők Kollégiuma holland trénerrel egy karakterelméletre épülö tréninget debreceni segítő szakembereknek, ami mások mellett Katona Mária számára is meghatározó élmény volt, önismeretéhez is, a terhek 
letételéhez is. Elfogadta, hogy vezetőként a saját karakterét kiegészítő karaktereket kell választani munkatársnak. A Kossuth Egyetemen 1988-ban közmüvelődési előadó egyetemi diplomát, 2000-ben mentálhigiénés szakember végzettséget szerzett. 2000-ben Vincze Béla is biztatta, hogy pályázza meg a Mobilitás Észak-alföldi Regionális Ifjúsági Szolgáltató Iroda vezetését. Földi Lászlót, a Mobilitás vezetőjét ma is nagyrabecsüléssel és szeretettel hivatkozza, ahogy Kátai Gábor hálózati igazgatót is. Katona Mária a Mobilitás Észak-alföldi Regionális Ifjúsági Szolgáltató Iroda vezetőjeként ellátta az Észak-alföldi Regionális Ifjúsági Tanács titkári feladatait is. A tanács elnöke Halász János volt, már politikusi pályája részeként. Így 2000-től közösen formáltak a regionális ifjúságpolitikát.

2013. március 1-vel szüntették meg a Mobilitást, Katona Mária 2013. március 15-re még miniszteri dicsérő oklevelet kapott munkája elismeréseként, de már munkanélküliként. Azóta nem foglalkozik különösebben ifjúsági munkával, a nemzetközi ifjúsági munkával foglalkozó honlapokra is csak ritkán tekint rá, néha Wootsch Péter blogját olvassa. Pár hónap munkanélküliség után lett módszertani munkatársa a Nemzeti Mủvelődési Intézet Szabolcs, majd Hajdú-Bihar megyei irodájának, ahol Jantyik Zsolttal volt közös programjuk. 2018 őszén nyugdíjba vonult, de az intézet kötelékeiben maradva félállásban egy pályázati program szakmai vezetője. Ma már nem aktív társadalmi szervezetekben. Úgy mondja, elhagyta azokat, amikor úgy érezte, már nem fejlődik a szervezet, nem futja azt a pályát, amire hivatott lehetne, és amiért ő tagként kötelezettségeket vállalt. De ha szükséges, nagyon szívesen ad tanácsot, ötletet. Úgy gondolja, az ifjúsági munka eredményességében a személyiségnek van meghatározó súlya, sokkal inkább, mint a közegnek.

„1980-ban végeztem a föiskolán, onnan kezdve egyenes az utam az ifjúsági munkában. Nem nagyon voltak elakadások, sőt, egyáltalán nem. Úgy éltem meg, hogy mindig sikerült feljebb lépnem az ifjúsági munka karrierpályáján. Az élet hozta, nem én küzdöttem érte. Valahogy mindig úgy történt velem, hogy amit éppen csináltam, abban eljutottam a munkatársaimmal arra a szintre, ahol már nem nagyon lehetett a lécet magasabbra tenni. Ami az egyik munkámban izgatott, hogy mi történik a fiatallal, a másik munkámban megtaláltam rá a választ, söt lehetöségem volt arra, hogy további lehetöséget kínáljak személyes életútjuk alakulásához. 35 évem van az ifjúsági munkában és nem volt kitérö. Egy nagy kegy az élettöl, hogy tényleg azt csináltam, amit szerettem.

Békéscsabán volt az elsö munkahelyem, az ipari szövetkezetek Gyopár klubjában. 4 évem volt ebben az ifjúsági klubban. A közmüvelödésben és az ifjúsági munkában is jó nevü kollégától vettem át a klubot. Azt gondoltam, ha sikerességében meg szeretném tartani a klubot, az csak úgy megy, hogy szövetséget kötök a régi tagokkal, de ök közben kiöregszenek majd, ezért újabbnál újabb fiatalokat kell bevonni a munkába. A fenntartó valamilyen ok miatt szemet hunyt felette, hogy ezek már nem az ipari szövetkezetek munkásfiataljai voltak, bár az volt az alapállás, hogy azért van ez a klub, hogy a munkásfiatalok szórakozását és müvelödését szolgálja. A városban élö fiatalok szivesen jöttek, akár müvészek is, nem elöadni, hanem hogy részesei legyenek a programnak, amit klubvezetöként kináltam. Azt mondták, azért jó ide lejönni, mert itt mindig olyanok történnek, amilyenek ebben a városban még soha. Ennek egy titka volt, szerintem, a tudatos értékközvetitésen túl, ami a munkámnak fontos eleme azóta is: teremtsük meg a csodát az adott pillanatban. Ha ehhez az kell, hogy elvarázsoljuk a teret, vagy 
az embereket, hát akkor azt tegyük! 1982-ben volt nálunk a Calcutta trió, a földön ülve zenéltek. Leültettük a közönséget is a földre, párnákra, indiai teát adtunk és a háttérbe az indiai kultúrát bemutató diaképeket vetítettünk az elöadás alatt. Az itt és most meghatározó élményét nyújtotta az este. Máig ható maradandó élmények. Azt gondolom, sikerült sokszor varázslatokat elérnem és ennek fontosságát a mindenkori kollégáimnak is átadni. Nagyon fogékonyak voltak a békéscsabai középiskolások erre, és köszönöm nekik, hogy visszaigazolásukkal ez a szemlélet tartóssá válhatott munkám során. Általában a befogadóképesség háromszorosát haladta meg a közönség létszáma. Féltünk, hogy jön a rendörség vagy a tüzoltóság, és azt mondja, ennyi ember nem tartózkodhat itt. Nyilván ebben a szakaszában az életemnek az volt a domináns, hogy meghatározó müvészegyéniségek jelenjenek meg a klubomban, és hasson a fiatalokra puszta létük, világról alkotott nézetük. Ha meghívtuk Hobót vagy Cseh Tamást, másokat, akkor biztosan sok nézö volt, és amikor elmentek a fellépök, akkor a klubban feldolgoztuk, hogy milyen üzeneteket hagytak itt. Ettöl lett közösség, nem csak rendezvényre járó emberek sokasága ez a százvalahány emberke.

Az ott töltött idöm második felében tudatosan érdekelt a közösséggé válás folyamata, hogy, mit is lehet, kell tenni annak érdekében, hogy igazi közösség legyen. Így kerültem kapcsolatba Vercseg Ilona közösségfejlesztővel, aki elinditott egy izgalmas vetélkedöt, amiben a Gyopár klub is részt vett. Levélben kapott feladatokat kellett elvégeznünk, melyek nagy része önismereti volt. Könnyebb volt játékos estet rendeznem, mert versenyeztünk közben. Volt olyan feladat is, hogy tervezzük meg, ha más városokból meghívnánk egy ifjúsági közösséget, mit ajánlanánk, mit föznénk nekik, hogyan épülne fel az egész napos program. Engem a felelösség átruházásában segített, a klubtagoknak meg a demokráciatanulás egyik - lehet, elsö - iskolája volt ez. Ebben is benne volt, hogy valami különös, a mindennapin túli szülessen.

Odajutottunk, hogy cikkeket irtak rólunk, én kiváló ifjúságiklub-vezetöi kitüntetést kaptam, rengeteg kapcsolatra tettünk szert országszerte. Az utolsó évre enyhült a politika, de figyelték, hogy miért járnak ebbe az ifjúsági klubba ennyien. Velünk szemben volt a pártbizottság, nem messze meg a rendörség. Ha Cseh Tamás megjelent, biztos ott volt a rendörautó. Elindítottuk a Mozgó Világ esteket, az akkoriban már eléggé jó periodika volt, fiatal, tehetséges írókkal, akik másként gondolkodtak a rendszerröl, találkozhattak velük a fiataljaink. Ez egyre inkább szemet szúrt. Kicsit meghurcoltak. Akkortól kezdve-azt hiszem-meg is figyeltek.

Négy év után, '84. március 15-én, eljöttem Békéscsabáról, új hazát választottam, így kerültem Debrecenbe, ifjúsági klubos kapcsolataim révén. A Hajdú-Bihar Megyei Állami Épitőipari Vállalat Ifjúsági klubjának a vezetője lettem. Akik a klubban már otthon érezték magukat, keményebb szabolcsi és Hajdú-Bihar megyei épitőipari munkásfiatalok voltak, alacsony iskolázottsággal. Ma azt mondanám, nem fontos szempont az ifjúsági munkában az iskolázottság. Nincs olyan embercsoport, akihez ne találnánk meg az utat. Ott az utam elsö lépésben az ultizással kezdödött. Meglepödtek, hogy tudok ultizni, jó szövetséget tudtam kialakitani velük. Olyannyira, hogy - amit az ember ritkán ér el - megnyiltak és még azt is elmondták, amit másoknak nem igazán. Beszéltek az életükröl, terveikröl, vágyaikról. Kifejezték, mit szeretnének. Azt is elmondták öszintén, hogy nekik lányokkal nehéz ismerkedniük, mert itt élnek ebben a városban, a munkásszállón. Így találnom kellett olyan közösségeket, ahová többnyire lányok jártak. Meghivtuk öket a klubestjeinkre, s számtalan 
olyan alkalmat teremtettünk, amikor ismerkedhettek, de akár a produkcióikat is bemutathatták. Azért volt számomra ez lényeges, mert rájöttem, nem az a fontos, hogy hirrességek lépjenek fel a klubunkban, hanem az, hogy a fiataljaink képessé váljanak arra, hogy megnyíljanak, elöadjanak bármit is, beszéljenek arról, ami öket foglalkoztatja, legyenek akár a legmélyebb vágyaik, legyenek tevékeny résztvevöi a folyamatoknak. Kitaláltuk a fiatalokkal, hogy legyen egy bál, amit mi rendezünk és más korosztályokat is meghívunk, söt az épitőipar vezetöit is. Nagy kihivás volt, hogy a szocreálos ebédlöböl hogyan lehet báltermet csinálni, és hogy azt is elérjem, hogy a klubtagok öltönyben, nyakkendöben jelenjenek meg. És végigcsinálni, hogy virág, szép terítő legyen az asztalokon, dekorációk, hogy ne látszódjon, hogy ez egy szocreál ebédlö. Közösen sikerült valamit létrehozni egy napra, amire ök is azt mondhatták: ez nem olyan volt, mint a többi nap. Ebben rengeteg munkája volt a munkásszálló fiataljainak, és szerintem tanultak is belöle valamit, mint ahogy én is. Persze nem tudtak viselkedni, és jöttek a rendörök. Nekem fontos volt ott is, hogy ne tegyék tönkre a munkámat. A fenntartó meg csak azt látta, hogy összetörték a wc-kagylót, ellopták a csapot, lehányták a wc-t. Úgy éreztem, hogy ez a munka fontos, szivesen csinálom. Amíg nem tudtam elérni, hogy ök takaritsanak ki a klubest után, addig én mindig hajnalban, a takaritónő elött, felkeltem és kitakaritottam a wc-t. Nem derogált. Azt gondoltam, hogy megéri. Különben bezárták volna a klubot. Nagyon komoly emberi kapcsolatokat tudtam kialakitani azokkal a fiatalemberekkel, a mai napig is szivesen gondolok rájuk. A klubnak a KISZ volt a fenntartója, és a vállalati KISZ-titkár volt az én fönököm. Nem nagyon tudtunk kijönni, mások voltak a szempontjaink, az értékeink. Az nem volt érdekes, hogy én KISZ-tag vagyok-e, nem jelentett elörelépést. Én még a föiskolán kiléptem, az volt a nehezebb, mert meg kellett indokolni, hogy miért. Pár szóbeli figyelmeztetést kaptam itt is. Kevesebb, mint két évig dolgoztam a munkásszálló ifjúsági klubjában. Akit helyettesitettem, visszajött a gyesröl.

Egy új közösségbe kerültem '85-ben, a Kossuth Egyetem Közmüvelödési Titkárságára, ifjúsági klubvezetönek, nagyon izgalmas területre. Mondhatnám azt is, hogy milyen nagyszerü elöadásokat szerveztem meg az egyetem aulájában, de nem ez volt a legfontosabb. És nem is az, hogy a Simonyi úti klubhelyiség heti programozása is feladatom volt. Amikor odakerültem, a legnagyobb probléma az egyetem és a város egymástól való elszigeteltsége volt. Kicsit azt is várták tölem, hogy próbáljam meg segíteni a közeledést. Ezt különleges elöadásokkal el lehetett érni, de nem a rendezvények szervezésében találtam meg igazán magamat, amelyeken a fiatalok is csak a közönség szerepét töltötték be, hanem a tényleges klubvezetöi munkában az egyetemistákkal. Úgy láttam, akármilyen képzésre járnak is, képesek megszervezni a saját világukat, és én, mint klubvezetö, abban tudom segíteni öket, hogy teret adjak az ö önszervezödésüknek. E törekvésemben találtam rá a Szép klubra, melyet Jantyik Zsolt és Halász János fémjelzett, mint egyetemi hallgatók, de tagjai voltak még Zsolt testvére, Jantyik Csaba, Jámbor Józsi (aki ma a Csokonai Színház színésze) vagy Herczegh Zoli, aki a PG zenekar alapító tagja volt és sokan mások. A Szép klub, úgy müködött kvázi, mint egy egyesület, bár akkor még nem született meg az egyesülési törvény. Szép táborokat szerveztek, melyek különlegességét az adta, hogy a tábori napok felében társadalmilag hasznos tevékenységet végeztek a táborlakók, például utcai padokat festettek, vagy takaritottak, csinositottak parkokat. A délután a kreativ tevékenységeké volt, melyeket az emlitett egyetemisták vezettek, majd világmegváltó esti beszélgetések zárták a napokat. A Szép táborok mellett lassan megalakult a 
Szép színpad is, melyet Jámbor Józsi vezetett. Ezen önszervezödések elfogadtatásában, megismerésében és belső tevékenységeik szakmai támogatásában merült ki munkám jó része. Sokat tanultam az egyetemistáktól és talán ők is tölem. Szerencsém volt, mert a fönököm, Petö Andor a Közmüvelödési Titkárság vezetöje inkább támogatott, mintsem akadályozott volna elképzeléseimben. Sajnos már 20 éve elment közülünk. Lassan belefáradtam az éjszakázásba, hiszen például Kósa Ferenc filmrendezőhöz még hajnali kettőkor is akadt kérdése a diákságnak, és mert egyedül voltam, a klubot meg nekem kellett bezárni.

Innen pont olyan helyre kerültem, ahol az eddigieket valahogy összegezni lehetett. Abban az időben jött létre a megyei tanácson az ifjúsági részleg a sportosztályon belül, mint az Állami Ifjúsági és Sporthivatal megyei leképezése. A 87-89-ben ott töltött éveim megint meghatározóak voltak. Azokban a klubokban, melyekben addig dolgoztam, azt a hiányt éltem meg, hogy nem látom majd, mi történt ezekkel az emberekkel évek múltán. Biztosan formálódtak, fejlödtek, de nincs meg az a közeg, amivel többet tudnánk adni, mint az eddigiekben. Teljesen új volt az ÁISH-nak ez a megyei ága, éppen ezért nem nagyon szóltak bele, hogy mit csináljunk. Csontos János $^{1}$ volt a fönököm. Lényegében azt csináltunk, amit akartunk. A települési önkormányzatoknál létrejött az ifjúsági referensi rendszer, és bár senki nem mondta, mi rájöttünk, hogy a mi feladatunk egyik része az ö szakmai munkájuk segitése lehet, így jelent meg számunkra a módszertani feladat. Az ÁISH-ból Wootsch Péterrel és Kovács Erzsivel álltunk kapcsolatban, azon gondolkodva, hogyan lehetne támogatni, tartóssá tenni a referensek munkáját. Akkor jelent meg a Péter által emlitett letéti számla ${ }^{2}$, mi magunk is sokat gondolkozunk ezen, a referenseket is bevontuk ebbe. A társadalmasitás és a szubszidiaritás elsö lépcsöfoka volt ez a forráselosztó rendszer. Szerintem nagyon jól müködött, nagyon szerettem ezt a részét a munkánknak. De persze, ha úgy gondoltuk, hogy a fiataloknak önismeretre, életvezetési tanácsadásra van szükségük, akkor szerveztünk önismereti tábort. Ami egyébként nem hivatali munka.

És volt még egy ága, amiről azt gondolom, hogy meghatározó volt: a nemzetközi kapcsolatok épitése. Az ÁISH-nak is volt ilyen küldetése. Hajdú-Bihar megyének az osztrák Voralberg tartománnyal akkor már testvérkapcsolata volt, és az én feladatom volt ennek ifjúsági tartalmat adni. Azt gondolom, az meg azért volt fontos, mert Vincze Béla nem tudta volna megcsinálni a Rocksulit, ha nem viszem el és egy jazzszemináriumban nem látta volna meg, milyen fantasztikus, hogy fiatalok fiatalokat tanitanak. Ott találkoztunk elöször müködö ifjúsági információs és tanácsadó irodával is. Oda vittünk el embereket, tanulmányútra, melynek eredményeképpen a megyénkben is létrejöttek ilyen irodák. Számtalan településközi kapcsolatot tudtunk elinditani.

Nagyon szerettem a referensek munkáját segiteni egy települési ifjúsági koncepciót elkészitésében, kezdve azon, hogyan gondolkodjon egy önkormányzat, hogy a fiatalok otthonosan érezzék magukat a településen, milyen forrásokat kellene az önkormányzatoknak

\footnotetext{
${ }^{1}$ Csontos János a püspökladányi jóhírü KIK klub vezetője volt a ’80-as években. A KIK és a Gyopár klub közös programjain már Katona Mária békéscsabai éveiben dolgoztak együtt.

${ }^{2}$ Lásd: Tóbiás, L. (2019). Szakmai életutak az ifjúsági munkában: Wootsch Péter - I. rész. Párbeszéd: Szociális Munka folyóirat, 6(2). https://ojs.lib.unideb.hu/parbeszed/article/view/3245 (Utolsó letöltés: 2020. 10. 18.)
} 
biztositaniuk? Ezek a gondolatok a megyei hivatalban dolgozva születtek meg, és ott is kisérleteztük ki ezeket.

Ebben a munkámban is elkezdtem érezni, hogy valami hiányzik, hogy valamit még teremtenünk kellene. Már az ifjúságiklubvezetö-képzés is leáldozóban volt. Ausztriában láttuk, hogy van ifjúságsegitö-képzés. Hoppá! Nálunk miért nincs? És akkor rájöttem, hogy egy csomó minden nincs nálunk: nincs ifjúsági törvényünk, nincs képzési rendszerünk, nincs módszertanunk. Viszont akkor kezdödött a szociális terület éledése. Hallgató Éváéknak, akik a közmüvelödési területen dolgoztak, jól müködö nyitott ház kísérletük volt ${ }^{3}$ a Csapókertben ${ }^{4}$ és a Szociális Iroda elkezdett dolgozni a szociális törvény elökészitésén, mindenki tett hozzá valamit az épitkezési folyamathoz, mi is saját eszközrendszerünkkel, és ebböl a folyamatból jómagam is nagyon sokat tanultam. Abban az időben már gondolkodtak a Szociális Munka Szakmai Etikai Kódexén. Abban is tudtunk segiteni. A nemzetközi ifjúsági cserékböl tudtuk, hogy ezek nyugaton régen létezö dokumentumok, amiket alapanyagnak felkínáltunk. Akkor kezdett el ezen a területen dolgozni Csoba Judit szociológus ${ }^{5}$ is, akit még az egyetemröl ismertem, akkor téli közmüvelödési gyakorlatokat is kellett vezetnem egyetemi hallgatóknak, amiket Judit koordinált. Késöbbi munkahelyeimen terepgyakorlatra fogadtuk Juditék hallgatóit. Farkas Attila is intenziven részt vett ebben a szakma alapjait lerakó mühelyben. Jó idöszak volt, és reményteli. Sokat tanultam a közigazgatás müködéséröl, a törvényalkotás folyamatáról. A késöbbi munkámban mintaként szolgált a szociális munka szakmaként való elismertetése. Ezek nagyon jó évek voltak, de átszervezés miatt ${ }^{6}$ az ifjúsági osztályt megszüntették, a sportosztály maradt a megyei hivatalban.

Az átszervezést követően a Kölcsey Müvelödési Központ igazgatója hívott, abban bizva, hogy az ifjúsági módszertani munkában egy fecske is csinálhat nyarat. Hamar kiderült, hogy nem. Bö három hónap múlva Vincze Béla hívott, hogy az ifjúsági információs és tanácsadó irodába dolgozzam mellette. Abban az irodában, melynek létrejöttéért a megyei tanács ifjúsági és sportosztályán szerepkörömböl adódóan is sokat tettem.

Debrecenben az ifjúsági információs és tanácsadó iroda 1988-ban, az ÁISH pályázata elsö körében alakult meg. Müködést 1989 decemberében kezdte meg hivatalosan. '90-ben kerültem oda. A pályázati kiirrás legföbb követelménye az volt, hogy a nyertes pályázó önkormányzatnak 5 évig kellett helyet és szakemberállományt biztositani a müködéshez. Ez nagyon európai gondolat volt, erre hazai példát akkoriban nem láttunk. Ma inkább az a gyakorlat, hogy születik

\footnotetext{
${ }^{3}$ Nyitott ház: „Az újkori magyar settlementet nyitott művelődési otthonnak nevezte el a két kezdeményező, Beke Pál és Varga A. Tamás (1975-től)." - lásd: Cselekvő közösségek - aktív közösségi szerepvállalás projekt wikikjét: https://cskwiki.hu/a-nyitott-haz-kiserlet/ (Utolsó letöltés: 2020. 10. 18.)

${ }^{4}$ Hallgató Éva-Herczeg Zoltán (1990): A közösségi ház modell Parola 1990/3 https://kofe.hu/parola/parolafolyoirat/a-kozossegi-haz-modell/ (Utolsó letöltés: 2020. 10. 18.)
}

${ }^{5}$ Prof. Dr. Csoba Judit 2020-ban a Debreceni Egyetem Bölcsészettudományi Kar, Politikatudományi és Szociológiai Intézet, Szociológiai és Szociálpolitikai Tanszéke egyetemi tanára, korábban tanszékvezetője, intézetvezetője, dékánhelyettese

${ }^{6}$ Az ifjúságügy a kormányzaton belül a miniszterelnökségre került, az ifjúságügy megyei és települési gondozása még esetlegesebbé vált. 
valami és nincsenek meg hozzá a garanciák. Él, prosperál egy ideig és aztán mintha nem is lett volna, elmerül a semmibe. A debreceni példa azért is érdekes, mert 5 év után nem volt kérdéses, hogy a város akarja-e tovább müködtetni. 20. születésnapját is megélte, szemben más városokkal, ahol jó, ha az első 5 év után még egy újabb öt év fenntartását vállalta az önkormányzat. Három évig voltam a Mezon Ifjúsági Információs és Tanácsadó Iroda módszertani munkatársa, Vincze Béla vezetése mellett, aztán én lettem a vezetö, mert Bélának nem volt meg az elöirt iskolai végzettsége. Béla még évekig ott maradt, később már inkább a Más-mozaik Szocikulturális Egyesületet szervezte. Bélával kiegészítettük egymást, ő volt a Nagy Álmodozó, a kísérletezö, én meg a rendszerszervezö, a megvalósitó. A Mezon 10. születésnapján a munkatársaktól sok ajándék, elismerés mellett egy-egy tokaji aszút kaptunk. Az egyik címkén Vincze Béla a Teremtö, a másik címkén Katona Mária a Megtartó szerepelt. Bár sok vitánk volt, jól kiegészitettük egymást. A Mezont is imádtam, mert közvetlenebb kapcsolatot tett lehetôvé a fiatalokkal. A Mezonban kezdetben elsödleges feladatom volt kitalálni, hogyan lehet az információt gyüjteni, tárolni és továbbitani. Tetszettek a tanácsadásaink: életvezetési, jogi, házi feladat segítése. Nagy öröm volt számomra, hogy ezeket csinálhattam, találkozhattam fiatalokkal. Fiatalos volt az intézmény kinézete, örömmel jöttek be az emberek. Hihetetlen nagy volt a látogatottság, amivel én, mint „elemzö” ember, nagyon elégedett voltam. Egy idö után hiányzott - az információ- és tanácsadás mellöl - a közösség. Ott voltak a fiatalok, és a személyiségünk - föleg Béláé, de bizonyos fokig az enyém is - vonzott bizonyos embereket. Kiderült, hogy trendi oda járni, és úgy érezni, a Mezon az én klubom. Pedig ez nem klub volt. Kialakult, hogy mi mezonisták vagyunk, mert oda járunk. Ök már nem azért jöttek, hogy megtudják, mikor lesz a koncert, vagy meddig tart, hogy otthon meg tudják mondani. Ez egy igazi kis közösség volt. Aminek életben tartása érdekében mindig ki kellett valami feladatot találni, amibe bevonhatjuk őket. Éppen jókor talált meg bennünket a nyári ifjúsági szolgálat müködtetésére kiírt központi pályázat. A mezonistákkal közösen találtuk ki a nyári ifjúsági szolgálatot, hogy a Debrecenbe jövö fiatalok kapjanak kérdéseikre - mikor, hol, mi, mennyiért stb. - választ, a mi fiataljainknak meg legyen értelmes elfoglaltsága. Öt pontot találtunk ki, ahol találkozhatnak a mezonisták külföldi és más településekről érkezö fiatalokkal, és felkészitettük őket, hogy információt tudjanak adni, tanácsot, ha szükséges. Zseniális dolog volt. Nagyon jó kis pólóink voltak. Egy fiatal lány egyszer azt kérdezte tőlem: Te, Mari, mit kell nekem ahhoz csinálnom, hogy én egy ilyen pólót kaphassak? Bekerült a csapatba. Imádta csinálni, nagyon jó animátor lett belöle. Rengeteget foglalkoztunk azzal, hogy a szolgálatban dolgozva hogyan kell megszólítani, milyen kultúrát, viselkedési módokat kell tanúsitani. Hol van a határa a megértésnek, türelemnek. Egész éjjel nyitva volt a Mezon a nyári szolgálat idején. Fogadtunk olyanokat is, akiknek nem volt, vagy elfogyott a pénze, kenhetett egy szelet májkrémes kenyeret, beszélgethetett a munkatársakkal, az önkéntesekkel, zenét hallgathatott. Hú, milyen különleges emlékek vannak ezekről az időböl! Hogy fiatalok milyen életpályát futnak be! Egy éjszaka odatévedt egy francia fiatalember, általunk ismert fiatalok meg a következö nyáron Franciaországban voltak, és ott utcazenéltek. Ezek a kapcsolatok a szolgálat nélkül nem jöhettek volna létre. Amit az alapításkor elvárt az ÁISH, annál mi sokkal szélesebb információs és szolgáltatási spektrumot találtunk ki és kínáltunk. 
A Mezonból is mentünk külföldi tanulmányutakra. Volt, hogy Vincze Bélával és a csapat többi tagjával egy punkzenekar foglalt házában ${ }^{7}$ aludtunk Münsterben, mert elakadtunk Luxemburgba menet. Az olasz, a német, az angol, a spanyol, a luxemburgi ifjúsági munkát a 90-es évek közepére már megismerhettem ezeknek az utaknak köszönhetöen. Nyitott volt a világ, és mi nagyon érzékenyek voltunk. Bélával szerettünk volna mindig valami újat csinálni, kicsit talán provokativan is. Csináltunk egy szociális részleget a Mezonnak. Volt egy szociális munkát tanuló munkatársunk is. Próbálkoztunk utcai szociális munkával is, mert úgy gondoltuk, a fiatalok egy részét elérjük, de az utcán élö fiatalokkal meg nem tudunk kapcsolatot teremteni. Nem voltak rosszak ezek a kísérletek, de annyira meghatározóak sem. Annyiban igen, hogy tudok három emberröl, akik ma is ezen a területen dolgoznak. Damu Ricsi például, akinek az Opera Egyesület a háttere és mai napig is ott van ezen a területen, rádiót müködtet, segélyeket szervez, van közösségi terük. Próbáltuk a szüknek látszó ifjúsági információs kört is kiterjeszteni. Arisztidékkal ${ }^{8}$ is sok mindent kitaláltunk. Próbáltuk az európai hálózatot megteremteni. Mi kaptuk meg elöször a HAYICO módszertani intézménye elismerö címet '99ben. Azt gondolom, azért értünk el sokat, mert mindig megtaláltuk a továbbfejlödési lehetőségeket, amiket a fiatalok hordoztak magukban. Nagyon szép tíz évem volt a Mezonban. Nemcsak Debrecenben, de országosan is fogalommá vált a Mezon.

Nem akartam én még elmenni a Mezonból, és nem is akart senki elküldeni, de 2000-töl jött az Ifjúsági és Sportminisztérium által kitalált új modell, a regionális ifjúsági szolgáltató iroda, ami felkeltette az érdeklödésemet. Pont azért, ami az egyik munkámban kiteljesedést adott, a másikban meg hiányt, hogy mi történik a fiatallal? Miben tudnánk még segíteni, hogy felelös, aktív felnötté váljon? Erröl az új modellröl gondoltam, hogy ez ötvözné mindazt, amit eddig csináltam. Mert ez alapvetően arra épült, hogy az ifjúsági közösségeknek, egyesületeknek, amik akkor már voltak, a szakmai és pénzügyi támogatást nyújtson. Azt mondtam magamnak, ez lehetne a szintézise, az eddigi munkámnak. A klubvezetéstöl, az önszervezödés, az önkormányzati ifjúsági munka támogatásán, az ifjúsági információs és tanácsadói munkán át az ifjúsági munka szakmává válásának segitéséig.

Vincze Béla biztatott, hogy pályázzam meg 2000-ben az Észak-alföldi Regionális Ifjúsági Szolgáltató Iroda vezetői állását. Megnyertem. 13 éven át dolgoztam ott. És azt mondhatnám, hogy az, amit mi álmodtunk, vagy amit én álmodtam, az 2010-ig megvalósulhatott. Az utolsó 3 évre a cselekvési tér elvesztése, a felülröl jövö feladatok végrehajtatása volt jellemzö, ami annyira nem volt nagy kihívás számomra.

Úgy érzem mindig sikerült kiváló szakemberekkel együtt dolgoznom. Itt a regionális ifjúsági szolgáltató rendszerben is nagyszerü emberekkel dolgozhattam együtt. Elsö 3 évben Vincze

\footnotetext{
${ }^{7}$ Foglalt ház: németül besetztes Haus, angolul: a squat. A tulajdonos által nem hasznosított, üresen tartott, gyakran valamilyen ingatlanspekuláció tárgyává tett lakóház, ritkábban ipari épület, amit a tulajdonos által fel nem hatalmazott emberek használatba vesznek, többnyire saját lakhatásuk céljára vagy hajléktan emberek számára. Közvetlen szükségletkielégítés mellett politikai tartalma is van: a lakhatási lehetőség kizárólag áruként való értelmezése elleni tiltakozás, de nem kötődik kizárólagosan valamely ideológiai irányzathoz, pl. Angela Merkel is élt foglalt házban.

8 Ditzendy Károly Arisztid a 90-es években a Kecskeméti Ifjúsági Információs és Tanácsadó Iroda és HAYICO Magyarországi Ifjúsági. Információs és Tanácsadó Irodák Szövetsége vezetője, később az Ifjúsági Minisztérium főosztályvezetője, még később, 2020-ban is HROD Közösségi Gazdaság- és Társadalomfejlesztési Központ vezetője, szakmai cikkek és kötetek szerzője.
} 
Béla is dolgozott irodánkban ifjúsági közösségfejlesztöként, majd külsősként segitette ifjúsági közösségek alakulását, megerösödését.

Az Ifjúsági és Sportminisztérium, mindenekelött Szabó László helyettes államtitkár részéröl különösen az elsö másfél évben sok segitséget kaptunk. Laci igyekezett rangot adni a tisztségünknek, és ahol az csak lehetséges volt az irodák szakmai munkáját más tárcákkal elismertetni. Laci nagyon sokat segitett abban, hogy bemutatott, egy darabig még kisérgetett is mindenkit, nem csak engem. Söt, ha Lacit, mint helyettes államtitkárt meghívták valahová a régióba, mennem kellett vele. Sokat tettek azért, hogy az irodáknak és tevékenységüknek rangja legyen, és ez hiányzik ma. Akkortájt rajta lehettem a protokoll-listákon, kaptam meghívókat eseményekre, de nem jártam megyebálokra és bemutató elöadásokra, ezek idegenek voltak tölem. Kiváló képzéseken vehettünk részt, hogy alkalmassá váljunk a regionális ifjúsági szolgáltató irodák küldetését beteljesiteni. A hálózat, a hét régió munkájának összehangolásán túl a személyes és szakmai kapcsolatok erösödése is hozadéka volt e képzéseknek. Létrejöttünkkor csak a fejlesztési ügynökségek müködtek régiós szinten. A mi irodahálózatunk volt a második, és bár hittem, hogy gombamód szaporodnak majd a különbözö regionális intézményrendszerek, ez nem következett be.

Nagyszerü és újszerü volt a szubszidiaritás elve szerinti pályázati rendszer, mely célt, eszközt és a szakmai fejlesztöi munkánkhoz lehetöséget biztositott. Miniszteri rendelet régiónként szolgáltató iroda és ifjúsági tanács felállitását rendelte el, és a kettöt összekapcsolta úgy, hogy az irodák, illetve azok vezetöi látták el a tanácsok titkársági feladatait, beleértve ebbe javaslattételi feladatokat is, a tanácsoknak meg elsödleges szerepköre a forráselosztás volt. ${ }^{9} \mathrm{Az}$ elsö évben 56 millió forint pályázati forrásról döntött a Regionális Ifjúsági Tanács az Északalföldi Régióban, Jász-Nagykun-Szolnok, Szabolcs-Szatmár-Bereg és Hajdú-Bihar megye pályázói számára. Nekem és a munkatársaimnak nagy kihívás volt jó pályázati kiírást elkésziteni, illetve ajánlásokat elöterjeszteni arra, hogy milyen célok megvalósulását támogassa a tanács. Azt hiszem az egyik legjobb együttmüködésben dolgozó iroda-tanács tandem volt a mienk. A tanács elnöke Halász János volt, akit még egyetemi hallgatói korából ismertem, kölcsönösen tiszteltük egymást. János megbizott szakmai javaslatainkban. Kiváló elképzelései voltak a civil ifjúsági közösségek támogatása tekintetében.

Igyekeztünk lendületet adni a szakembereknek, az ifjúsági közösségeknek, elösegíteni, hogy tudjanak egymásról. Éves szinten regionális ifjúsági találkozó megrendezésére is irtunk ki pályázatot, azt is pontosan leírtuk, mit kell tartalmaznia a találkozónak. 2001-ben volt az elsö, Matfün, melyet további három regionális ifjúsági találkozó követett. Ilyen jellegü pályázati kiírás és megvalósult program nem volt más régióban.

Szervezetek müködésének és a nyári táboroknak a támogatása mellet a régiónk mindig valami új dologgal állt elö. Így a regionális ifjúsági tanács írt ki pályázatokat kutatásokra is. Az egyik nyertes pályázó a Hajdúsági Hallgatókért és Civilekért Egyesület, a Ha-Ha volt, amely Murányi

\footnotetext{
${ }^{9}$ Az ifjúsági és sportminiszter 2/1999. (IX. 24.) ISM rendelete a Gyermek és Ifjúsági Alapprogram és a Regionális Ifjúsági Irodák müködéséröl. A 2020-ban is hatályos, de sokat változtatott rendelet eredeti szövege a Magyar Közlöny archívumában érhető el: Magyar Közlöny 1999/85. szám 5410. oldal
} 
Istvánnal ${ }^{10}$ közösen készitette el az Észak-alföldi régió ifjúsági szervezeteinek küldetéstudatának vizsgálatát is ${ }^{11}$. Az egyesülettel szoros szakmai együttmüködése alakult ki a későbbiekben az irodának. Céljaink nagyon hasonlóak voltak, és ök civil szervezetként pályázatokon tudtak pénzt szerezni, igy konferenciákat és képzési programokat valósitottunk meg az iroda és a Ha-Ha közös rendezvényeként. 2010 és 2013 között az év régiós ifjúsági történéseit és eredményeit bemutató rendezvényt a Ha-Ha finanszírozta. Amikor megszüntünk, akkor még Laciékkal csináltunk egy záró rendezvényt, pedig amikor felhívtak Budapestre március 1-jén, akkor azzal küldtek el mindannyiunkat, hogy holnap már be sem kell mennünk. A könyvtárunk nagy részét is ez a szervezet vitte el. 13 év alatt nagyon sok könyvet gyüjtöttünk össze! A Ha-Ha készitette el a tanács pályázati kiírására a Gyémántcsiszolók címü kiadványt ${ }^{12}$, mely a régió jó példával szolgáló ifjúsági civil szervezeteit mutatta be. Az egyesület vezetője, Hamvas László nagy barátja volt Kátai Gábornak. Tudtunk együtt gondolkodni sokszor hármasban. Gábor lejött Debrecenbe és éjszakákon át beszélgettünk hármasban.

Évente rendeztünk két-három konferenciát is. Elsödleges célunk mindig az volt, hogy teret kapjanak a régió ifjúsági civil szervezetei, hogy egymás értékeit ismerjék meg és tanuljanak egymás jó gyakorlataiból. „Látni és láttatni” ez volt a szakmai szlogenünk. Amíg volt a regionális pályázati rendszer, abból sok információhoz jutottunk, ami abban segített, hogy hol, mely területeken szükséges fejlesztési folyamatokat inditanunk, képzéseket szervezni.

Egy tanulmányút keretében Hollós Jocó vendége lehettem Bécsben, aki a városi önkormányzat ifjúsági föosztályvezetöje volt évtizedeken át, irigylésre méltó ötletekkel és feltételek között. Ott hallott ötletböl terjesztettünk elö javaslatot az ifjúsági tanács számára az ifjúságbarát önkormányzat dijj megalapítására. 2010-ig 5 település nyerte el az „Ifjúságbarát önkormányzat" címet. Ilyen pályázati kiírás más régiókban nem volt, ahogy ifjúsági magazin müsor támogatása sem. Mi arra jöttünk rá, hogy amit a közösségek csinálnak, az rejtve marad. Arról inkább szólnak az újságok, hogy a Riska tehén kettőt ellett. Hogy egy közösség mit miért csinál, az általában nem jelenik meg napilapokban vagy híradókban. Mi, illetve közvetve a regionális ifjúsági tanács ifjúsági magazinmüsorra adtunk megbizást a helyi televíziónak, hogy hetente fél órában ifjúsági tartalmakat szolgáltasson. Ez nagyon jó volt, szerintem sokat segitett ismertebbé tenni a munkánkat, meg azokat a közösségeket, akiket a mi ajánlásunkra meglátogattak. Késöbb - látva, hogy a hivatalos média csak egyféleképpen tud gondolkodniazt javasoltuk a tanácsnak, hogy olyan civil szervezeteket hívjon meg pályázatba, melyek vállalják a müsorkészitést, és több megyét elérve, heti rendszerességgel játsszák le a felvett 30 perces müsort. Egy csomó civil szervezetet találtunk, akik képesek voltak erre. Egy civil szervezet a civil létéböl fakadóan jobban tudta ezeket a müsorokat megszerkeszteni.

\footnotetext{
10 Dr. Murányi István a Debreceni Egyetem Szociológia és Szociálpolitika Tanszék docense, szerteágazó érdeklődésű kutató, ifjúságkutatással is foglalkozik.

${ }^{11}$ Murányi István (2006): Észak-alföldi ifjúsági szervezetek küldetéstudata. Hajdúsági Hallgatókért és Civilekért Egyesület, Debrecen

${ }^{12}$ Bánfalvi Győző, Hamvas László, Üveges Tamás (szerkesztők) (2004): Gyémántcsiszolók: az Észak-Alföldi Regionális Ifjúsági Tanács támogatásával megvalósult programok. Hajdúsági Hallgatói Önkormányzatok Kulturális Egyesülete, Debrecen http://www.unp.hu/sites/default/files/imuk/pdf/gyemantcsiszolok.pdf (Utolsó letöltés 2020. 10. 18.)

Gyémáncsiszolók2 (2013) - $\quad$ A $\quad$ kötetben hiányosak a könyvészeti adatok http://www.unp.hu/sites/default/files/imuk/pdf/gyemantcsiszolok_2.pdf (Utolsó letöltés 2020. 10. 18.)
} 
Tartalmasabbak voltak. Ez is ment vagy öt évig a munkánk révén, a tanács támogatásával. A mai nap is azt mondanám, hogy kellenének ilyen müsorok.

A tanács forráselosztó tevékenysége az évről évre apadó költségvetési keret ellenére 2010-ig tartott. Az utóbbi évek forráscsökkenését már az irodánk is megérezte, hiszen a szakmai munkára is kevesebb jutott, de az igazi veszteség inkább abban volt mérhetö, hogy már nem láttuk annyira a régió civil szervezeteit, nem volt közvetlen visszacsatolás, nem láttuk erösségeiket, gyengeségeiket és lehetöségeiket. Míg volt regionális pályázati rendszer, addig volt pályázati monitorozás is, melyet az iroda látott el. Ezek voltak a visszacsatolások, melyekböl képesek voltunk új, hatékony módszereket kikísérletezni és alkalmazni.

A látótér és cselekvési tér beszükülésére, melyet egyrészt a tanács forráselosztó tevékenységének megszünése is eredményezett, az önkormányzatokkal való tudatos foglalkozással válaszoltunk. Azt hiszem, ez is csak a mi irodánk vállalása volt. Ehhez kellett, hogy belépjen munkatársnak egy szociológus, akivel beszélgetve jutottunk arra, hogy meg kellene néznünk, milyen szereptudatuk van a polgármestereknek a településükön élö fiatalokkal való foglalkozás terén. Igyekeztünk minél több polgármestert meglátogatni. Beszélgettünk arról, hogy amikor elinditanak egy tizéves tervet, akkor tudniuk kell, hogy a mostani fiatallal tíz év múlva mit akarnak csinálni. Néhány helyen volt aha-élmény, otthagytuk ezt a gondolatot. Szerintem eléggé sikeres időszakunk volt, próbáltunk lámpákat gyújtogatni. Interjúkat is készitettünk, született egy kis könyv. ${ }^{13}$ Egy olyan könyvet akartunk összehozni - és sikerült is szerintem -, ami a késöbbiekben útmutató lesz az önkormányzatok számára, hogy a fiatalokat, az ifjúsági munkát hogyan tudnák támogatni települési szinten. Arról is irtunk, milyen szakembereknek kellene lenniük az önkormányzatoknál, mik azok a jó példák, és hogy a stratégiai tervekben legyenek benne a fiatalok.

Már a Mezonban is fontosnak tartottam a magunkról való kommunikációt. Ott is volt lapunk, Mezon-más címen ${ }^{14}$, ami a hírek közzététele mellett ösztönözhette is akár a fiatalokat, hogy érdemes valamit csinálni, egyesületet is alakithatnak. A Mobilitásnál is volt lapunk, a Mátrix ${ }^{15}$, azt hiszem, az is országosan egyedülálló volt az irodák körében. Szerették is, meg tartalmas is volt. Törekedtünk rá, hogy mindig legyen benne módszertani ajánlás, módszerleirás.

Elkészült Bánszegi Zsuzsa kolléganöm könyve, Az ifjúsági munka fogalomtára ${ }^{16}$ is és egy másik könyve a fiatalok társadalmi részvételéröl ${ }^{17}$. Nagyon sokat vártuk, hogy Wootsch Péter végre megírja az Otthonosan itthon címü könyvét ${ }^{18}$ az ifjúsági munkáról. Valami akkor szakma, ha van irodalma is, amiböl lehet tanulni. Innen jött az ötlet, hogy teremtsük meg az ifjúsági munka könyvtárát. Elöször DVD formájában jelent meg, majd később az az ötletünk támadt, hogy

\footnotetext{
${ }^{13}$ Kollár-Éri István (2009): Fiatalok a hivatal ablakán túl - Fiatalok a hivatal ablaka mögül 2009. In: Kollár-Éri István (szerkesztő) (2009): Észak-alföldi Regionális Ifjúsági Helyzetelemzés Foglalkoztatási és Szociális Hivatal Mobilitás Országos Ifjúsági Szolgálat Észak-alföldi Regionális Ifjúsági Szolgáltató Iroda

${ }^{14}$ Lásd: https://en.mandadb.hu/tetel/47275/MezonMas_ujsag_1994_majus

${ }^{15}$ Az Országos Széchenyi Könyvtárban 2000-2005 között megjelent 6 példány található meg.

${ }^{16}$ Bánszegi Zsuzsa (szerkesztő) (2006): Az ifjúsági munka fogalomtára: az ifjúsági munka területéhez kapcsolódó fogalmak gyüjteménye. Ifjúsági Munkások Szakmai Módszertani Egyesülete. Debrecen

${ }^{17}$ Bánszegi Zsuzsa (2009): Fiatalok társadalmi részvétele FSZH, Budapest

${ }^{18}$ Wootsch Péter (2009): Otthonosan itthon: települési ifjúsági munka - az otthonosság megközelítései. Mobilitás könyvek / Foglalkoztatási és Szociális Hivatal, Mobilitás Országos Ifjúsági Szolgálat, Budapest
} 
legyen egy honlapja, ami folyamatosan frissül, bövül. Nagyon szép tartalmas és hiánypótló volt a www.ifjusagimunkakonyvtara.hu oldalunk. Százvalahány elektronikus könyv volt benne. Nem régen hivott egy akkori kolléganöm, hogy egy mostani képzési anyagban hivatkoznak az irodánk módszertárára. És az a honlap már nem is müködik! Megcsináltuk az Ifjúsági Munka Könyvtárát, az Új Nemzedék lenyúlta. Ilyen az élet, de az nagyobb baj, hogy most már nem is lehet elérni sehol sem! Összekapcsoltuk az eszközeinket: a Mátrix beszámolt róla, ha feltettünk egy új darabot a könyvtárba. Ha láttuk, hogy valami megjelent, kértünk hozzájárulást a könyvtárunkba való felhelyezésre. A módszertárunk is jó volt. Szerettük csinálni, és azt éreztük, hogy van értelme. Szabad volt a pálya, és mindig tudtunk reagálni az új dolgokra, új igényekre. 2010 táján azt láttuk, hogy a fiatalok vállalkozóvá válását is kellene segítenünk. Ez egy új irány volt. Az elsö ilyen konferenciát az elsö debreceni romkocsmában, a Roncsbárban rendeztük meg a szabad ég alatt. Különös hangulata volt és jó felvezetés, hozzájárulás e probléma kezelésének.

Számtalan kezdeményezésünk közül megemlitenék még egyet, mely elég egyedi volt, és aminek Fogócska volt a neve. Ott vártuk a fiatalt Nagyrábén a buszmegállóban - meg még számtalan más településen a régióban - mert tudtuk, melyik busszal jön majd az iskolából. A dolgok lényege mindig az, hogy zökkentsd ki a hétköznapjaiból! Hívd fel magadra a figyelmét, hogy elgondolkozzon! Volt, hogy pingpongozni hivtuk öket, és közben megtudhatták, hogy nyelvet tanulhatnának egy európai országban, részt vehetnének egy csónakfestö projektben. Ezek egy európai ifjúsági programnak a promotálási alkalmai voltak. Sokat tanultunk ezekböl is, és ezek hatására régiónkban az európai önkéntes program szépen felfutott.

Amit az ifjúsági tanács és a szolgáltató iroda képviselt az Észak-Alföldön, azt lehet az ifjúsági munka egy irányzatának tekinteni. A hét regionális ifjúsági szolgáltató iroda közül a dél-alföldi volt még, mely igyekezett egyéni utakat keresni a régióban jelentkezö ifjúsági problémákra, kihívásokra. Egészséges verseny volt közöttünk. Sokat meritettünk egymás munkájából, tapasztalataiból. Talán ez a magyarázat arra, hogy miért jutott el a hírünk a nyugati országrészekbe is, mindkét iroda kreatív megoldásokkal tudott válaszokat adni az ifjúsági kérdésekre. Mi már akkor úgy tekintettünk a fiatalokra, mint eröforrásra, amikor ez még kormányzati szlogenként nem jelent meg. És ez benne volt a mindennapjainkban, amiért és amiket csináltunk, és ahogyan, amiket szerettünk volna eredményként elérni, abban mindenben. Azt akartuk, a képzések is afelé menjenek, hogy a fiatalok megtanulják megfogalmazni a szükségleteiket, képviselni az érdekeiket. És ezekben eléggé következetesek voltunk. Talán erre utalt Wootsch Péter, hogy mi Vajda Árpiékkal ${ }^{19}$ igyekeztünk mindig magasabbra tenni a mércét. „Jót, s jól.” - Vincze Béla hozta ezt elö egyszer egy letisztult pillanatban velem kapcsolatban: Mari mindenben a „Jót, s jól!’”-t tartja szem elött. És rájöttem, hogy igaza van, mert mindig ez vezetett. Igyekeztünk a közösségeket támogatni. Amire én büszke lehetek ebböl a 13 évböl, az az, hogy viszonylag jól találtuk meg a továbblépési lehetöségeket.

Hogy a képzési rendszer beindult, az szerintem nagyszerü eredmény. (Zárójelesen jegyzem meg, hogy Nagy Ádám bizonyos tekintetben többet tudott letenni az asztalra a szakmává válást segítö iskolarendszerü ifjúsági képzési rendszer megteremtése érdekében, mint a Mobilitás, bár a

\footnotetext{
${ }^{19}$ A Mobilitás Dél-alföldi Regionális Ifjúsági Szolgáltató Iroda vezetője és munkatársai.
} 
képzési anyagok jelentös részét a Mobilitásban dolgozó kollégák készitették, de ennek így ma már nincs is jelentősége, hiszen az ifjúságsegitö-képzés végül is elindult 2010 körül, és a képzés tananyagává vált az Ádám által gondozott gyüjtemény ${ }^{20}$. De más volt az alap, amivel nem tudtam egyetérteni, sokakkal együtt. Különbözö helyekröl indultunk. Az ifjúsági munkáról azt gondoltam, amit Wootsch Péter, aki egy kicsit a tanitómesterem is volt, meg Kovács Erzsi, hogy a felelös felnötté válás és a részvétel segitése az ifjúsági munka lényege, a hozzávezetö utakban, módszerekben, formákban azonban nagyon különböztünk Ádámtól.)

A regionális ifjúsági szolgáltató irodában töltött időszakot én úgy éltem meg, hogy be kéne pótolni, amit elmulasztottunk. El kellene ismertetnünk az ifjúsági munkát, mint szakmát, kellene jogszabályi háttér és képzési rendszer. Mindenféle jogszabály-elökészitö munkában aktívan részt vettünk. Vitáztunk. Nem sok eredménye lett. Bár Kátai mindig azt mondta, a norvégoknál hárommondatos az ifjúsági törvény. Valahogy így: az a kötelessége minden kormányzatnak és önkormányzatnak, hogy a fiatalok felelös felnötté válását segitse elö. És ebben rengeteg minden van, ami egy másik kultúrában természetes: hogyan kell adni nekik esélyt, hogyan kell a véleményüket kikérni. Nekünk meg nincs ehhez kultúránk. De azért mi is készitettünk valamit .. $a$, „...Hogy általunk legyen jobb!” Nemzeti Ifjúsági Stratégia 2009-202421 elkészitésében is sok munkánk volt..., meg még sokaknak...

Mindig az volt a legnehezebb, amikor megkérdezték, hogy neked mi a foglalkozásod, mit csinálsz, egyrészt azt gondolták, drogos fiatalokkal foglalkozom. Olyan nehéz volt azt elfogadtatni, hogy nem, az pont nem, az egy másik szakmaterület. Nekem mindig az volt a legfontosabb, hogy a szakmaterületek kompetenciái ne mosódjanak széjjel, de a kapcsolat legyen meg. Az információs iroda arra tanitott, segitenünk kell, hogy a fiatal A-ból B-be eljusson, de B-nek is léteznie kell. Ha nem létezik, azt kell segiteni, hogy az létrejöjjön. Vincze Bélával annyi gyártelepet néztünk ki a '90-es években a városban, hogy abból mit lehetne csinálni! Volt egy malomépület, ma már szálloda van benne. Luxemburgban láttuk: ifjúsági szálláshelyet, képzőhelyet kell csinálni, amit fiatalok müködtetnek, saját kultúrájuk szerint alakitva a rendjét.

Mi épiteni, teremteni szerettünk volna még, de 2013. március 1-vel egy tollvonással megszüntették a Mobilitás regionális ifjúsági szolgáltató irodai hálózatát. Budapesten közölték velünk, hogy megszününk, hazajövök, és a postaládában a levél, hogy Navracsics Tibor miniszter úr március 15. alkalmából miniszteri dicséretet szeretne nekem átadni, és nyilatkozzak, hogy elmennék-e az ünnepségre. Azt gondoltam, ez a sors iróniája, de azt mondtam, csak elmegyek. És amikor átvettem a kitüntetést, úgy gondoltam, nekem csak el kellene mondani a miniszter úrnak, hogy: Miniszter Úr, Ön most engem kitüntetett, de nekem most nincs már munkahelyem. - Hogyhogy? - Mondom: megszüntették a munkahelyemet. És akkor állt, és mondta: Na, én ezt nem értem. És szólt valakinek: Ez a hölgy azt állítja, hogy neki nincs munkahelye és hogy a Mobiltás megszünt. Akkor került ki a nyomdából a regionális ifjúsági tanács támogatása révén az említett Gyémántcsiszolók kötetet, gondoltam, egyet csak

\footnotetext{
${ }^{20}$ Földi László, Nagy Ádám dr. (szerkesztők) (2010): Ifjúságügy ifjúsági szakma, ifjúsági munka Módszertani kézikönyv. Mobilitás-Ifjúságszakmai Társaság Alapítvány-Új Mandátum Kiadó, Budapest

${ }^{21}$ 88/2009. (X. 29.) OGY határozat a Nemzeti Ifjúsági Stratégiáról
} 
adok Navracsics miniszter úrnak, hogy ezek voltak az erősségek a mi munkánk során, ezek a közösségek jöttek létre, erősödtek meg, és egy tollvonással most meg megszüntünk. Olyan kellemetlen volt, szerintem neki is. Én meg úgy gondoltam, hogy nekem ezt el kellett mondanom, mert rettenetesen sok sérelem volt bennem akkor.

Két hónapig munkanélküli voltam. Halász János segitségével kaptam állást a Nemzeti Müvelödési Intézetben, módszertani referensként. János szerint én is mindent megtettem, sokszor az állásomat is veszélyeztetve, hogy a Szép klub az egyetemen belül müködhessen annak idején. Ezért segitett.

A módszertani munkámban a jó gyakorlatokkal foglalkoztam, azt láttam, nincs leírva mitöl jó egy gyakorlat. Azt hiszem, sikerült egy jó meghatározást alkotnom, bár még nem terjedt el. Az is foglalkoztatott, hogyan lehet azt az intézeti müködésébe integrálni. Másik feladatköröm a megyei módszertani munkám mellett az önkormányzatok szemléletformálása volt, tapasztalati tanulási módszerek által. Látóút néven polgármestereket vittünk el jó gyakorlatot folytató településekre. Látóutak szervezésében és megvalósitásában 4 évig Jantyik Zsolttal dolgoztam együtt, aki az intézeti tanácsadói szerepköre révén lett a harmadik fönököm. Tapasztalati tanulási programjainkkal hozzájárultunk, hogy az intézet láthatóbbá vált, és hogy számtalan település elindult azokba az irányokba, melyeket, mint kulturális gazdaságfejlesztési jó gyakorlat, bemutattunk a látóútjaink során.

'18 novemberében nyugdíjba mentem módszertani referensként, azóta egy pályázati program szakmai vezetöje vagyok az intézetben.

Ma már valahogy nincs civil aktivitásom. Korábban fontos volt a Barakonyi Patakvölgy Egyesület, amit Tornabarakony, egy kihalófélben levö ruszin település megmaradása segítéséért alapitottunk. Elmaradtam belöle, mert nem láttam, hogy a célt érhetnénk, ahogyan és amerre haladtunk. Korábban is dolgoztam eléggé sok egyesületben, de amikor úgy éreztem, hogy nem fejlödik, vagy megváltozott a szellemisége, amiért az elkötelezödést vállaltam, kiléptem, elhagytam azokat."

Debrecen, 2020. július-augusztus 